\section{DiscoverSys \\ Published by DiscoverSys \\ Family functioning, social support and quality of life among elderly in the Public Health Center III South Denpasar}

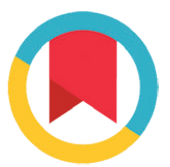

CrossMark

\author{
Dewianti, ${ }^{1 *}$ Kadek Tresna Adhi, ${ }^{1,2}$ R.A. Tuty Kuswardhani ${ }^{3}$
}

\section{ABSTRACT}

The elderly population has increased alongside with the increasing of life expectancy in elderly. Unfortunately, this is not followed by increased quality of life among elderly. Interview with 10 elderly at the Public Health Center III South Denpasar revealed that they experienced loneliness and felt neglected which affect their quality of life. This study aims to determine the relationship between family functioning, social supports (friends, family and community) and quality of life of elderly at the Public Health Center III South Denpasar in 2013. This study is a cross-sectional, involving 125 elderly who still have a partner and was selected using systematic random sampling method. Agreed participants were interviewed to obtain data related to family function, social support (partner, family and community) as well as their quality of life. Data were analysed using univariate, bivariate and multivariate. Statistical testing used were chi-square test and logistic regression. The study revealed that most of the elderly has a low quality of life (62.4\%), a low family functioning (72\%), lack of family support (54.4\%) and lack of community support (67.2\%); however, most of them has a high support from their partner (54.4\%). The chi square test result showed that function of family, social support (friends, family, and community) were significantly associated with quality of life in elderly $(p<0.05)$. Results of logistic regression showed that function of family has a significant relation with quality of life in elderly $(p<0.05)$. It can be concluded that better family functioning improves the quality of life in elderly.

Keywords: elderly, function of family, social support and quality of life Cite This Article: Dewianti, Adhi, K.T., Kuswardhani, R.A.T. 2013. Family functioning, social support and quality of life among elderly in the Public Health Center III South Denpasar. Public Health and Preventive Medicine Archive 1(2): 134-138. D01:10.15562/phpma.v1i2.176

\title{
Fungsi keluarga, dukungan sosial dan kualitas hidup lansia di wilayah kerja Puskesmas III Denpasar Selatan
}

\section{ABSTRAK}

Jumlah penduduk lansia dari tahun ke tahun mengalami peningkatan seiring dengan bertambahnya usia harapan hidup. Peningkatan kuantitas lansia tidak diikuti dengan meningkatnya kualitas hidup lansia. Hasil wawancara dengan 10 orang lansia di wilayah kerja Puskesmas III Denpasar Selatan menunjukkan bahwa mereka mengalami kesepian dan merasa tidak diperhatikan sehingga mempengaruhi kualitas hidup. Penelitian ini bertujuan untuk mengetahui hubungan fungsi keluarga, dukungan sosial (pasangan, keluarga dan masyarakat) dengan kualitas hidup lansia di wilayah kerja Puskesmas III Denpasar Selatan. Penelitian cross sectional telah dilaksanakan terhadap 125 orang lansia lakilaki yang masih memiliki pasangan dan dipilih secara systematic random sampling. Masing-masing sampel yang sudah memberikan pernyataan persetujuan (informed consent) kemudian diwawancarai untuk mendapatkan data fungsi keluarga, dukungan sosial (pasangan, keluarga dan masyarakat) serta kualitas hidup lansia. Data dianalisis secara univariat, bivariat dan multivariat dengan uji statistik chi square serta regresi logistik. Hasil penelitian menunjukkan bahwa sebagian besar lansia dengan kualitas hidup kurang $(62,4 \%)$, fungsi keluarga kurang $(72 \%)$, dukungan sosial keluarga rendah $(54,4 \%)$ dan dukungan sosial masyarakat rendah $(67,2 \%)$, sedangkan dukungan sosial pasangan sebagian besar dalam kategori tinggi yaitu 54,4\%. Hasil uji chi square menunjukkan bahwa fungsi keluarga, dukungan sosial (pasangan, keluarga dan masyarakat) berhubungan secara bermakna dengan kualitas hidup lansia $(p<0,05)$ dan hasil uji regresi logistik menunjukkan bahwa fungsi keluarga memiliki hubungan bermakna dengan kualitas hidup lansia $(p<0,05)$. Fungsi keluarga yang baik meningkatkan kualitas hidup lansia, dengan demikian perlu upaya peningkatan fungsi keluarga oleh anggota keluarga yang memiliki lansia.

Geriatric Division Sang Hospital - Faculty of Medicine, Udayana University

"Correspondence to:

Dewianti, Public Health Postgraduate Program Udayana University

wi2k_aj3g@yahoo.com
Kata kunci: lansia, fungsi keluarga, dukungan sosial dan kualitas hidup Kutip artikel ini: Dewianti, Adhi, K.T., Kuswardhani, R.A.T. 2013. Fungsi keluarga, dukungan sosial dan kualitas hidup lansia di wilayah kerja Puskesmas III Denpasar Selatan. Public Health and Preventive Medicine Archive 1(2): 134-138. D0l:10.15562/phpma.v1i2.176 


\section{PENDAHULUAN}

Kemajuan di bidang kesehatan, meningkatnya sosial ekonomi masyarakat dan pengetahuan masyarakat mengakibatkan meningkatnya kesejahteraan rakyat dan peningkatan usia harapan hidup. Peningkatan usia harapan hidup mempengaruhi jumlah penduduk lanjut usia (lansia) dari tahun ke tahun yang semakin meningkat ${ }^{1}$. Jumlah lansia di Indonesia pada tahun 2006 adalah sebesar 19 juta (8,9\%) dengan usia harapan hidup 66,2 tahun. Jumlah ini naik menjadi 23,9 juta $(9,77 \%)$ di tahun 2010 dengan usia harapan hidup 67,4 tahun. Pada tahun 2020 diperkirakan akan meningkat menjadi 28,8 juta $(11,34 \%)$ dengan usia harapan hidup 71,1 tahun $^{1}$.

Angka harapan hidup di Provinsi Bali lebih rendah dari angka nasional yaitu sebesar 70,6 tahun, namun besarnya populasi lansia $(11,02 \%)$ di Bali menempati peringkat 4 setelah Provinsi Yogyakarta, Jawa Tengah dan Jawa Timur. Kota Denpasar sebagai salah satu kabupaten di Bali juga memiliki populasi lansia yang lebih besar yaitu sebesar $16,76 \%$ pada tahun 2011. Jumlah lansia di wilayah kerja Puskesmas III Denpasar Selatan tahun 2012 yaitu 646 orang. ${ }^{2}$

Meningkatnya jumlah populasi lansia berdampak terhadap penurunan kualitas hidup lansia, seperti penurunan kapasitas mental, perubahan peran sosial, kepikunan, serta depresi. ${ }^{3}$ Hasil survei awal terhadap 10 lansia didapatkan bahwa 7 orang lansia (70\%) mengalami penurunan kualitas hidup terutama dalam rasa kesepian dan kurangnya perhatian dari anggota keluarga lain. ${ }^{3}$

Rendahnya kualitas hidup lansia sering dihubungkan dengan fungsi keluarga dan dukungan sosial, baik dukungan sosial dari pasangan, keluarga ataupun masyarakat. ${ }^{4}$ Hasil wawancara pada lansia di wilayah kerja Puskesmas III Denpasar Selatan diperoleh bahwa sebagian besar lansia dengan fungsi keluarga kurang (64\%), sebagian besar lansia mendapatkan dukungan sosial yang rendah baik dari pasangan (56\%), keluarga (62\%) dan masyarakat (60\%). Berdasarkan hal tersebut, dilakukan penelitian untuk mengkaji hubungan antara fungsi keluarga dan dukungan sosial (pasangan, keluarga dan masyarakat) dengan kualitas hidup lansia.

\section{METODE}

Penelitian cross sectional ini melibatkan lansia yang masih memiliki pasangan di wilayah kerja Puskesmas III Denpasar Selatan yaitu sebanyak 125 orang yang dipilih dengan systematic random sampling. Lansia yang memberikan persetujuan (informed consent), selanjutnya diwawancarai untuk mendapatkan data mengenai fungsi keluarga, dukungan sosial pasangan, keluarga dan masyarakat serta kualitas hidup. Variabel fungsi keluarga dan dukungan sosial diukur dengan menggunakan Adaptation Partnership Growth Affection Resolve (APGAR) dan variabel kualitas hidup lansia diukur dengan menggunakan World Health Organitation Quality of Life (WHOQOL).

Data selanjutnya dianalisis secara univariat, bivariat dan multivariat. Uji statistik chi square dipakai untuk menilai hubungan antara variabel fungsi keluarga, dukungan sosial pasangan, keluarga dan masyarakat dengan kualitas hidup lansia, sedangkan uji regresi dipakai untuk menguji faktor yang paling dominan berhubungan dengan kualitas hidup lansia.

Penelitian ini telah dinyatakan laik etik oleh Komisi Etik Penelitian Fakultas Kedokteran Universitas Udayana/Rumah Sakit Umum Pusat Sanglah Denpasar.

\section{HASIL}

Hasil analisis secara dekriptif menunjukkan bahwa sebagian besar responden berumur 60-74 tahun (65 orang; 52,0\%), sebagian besar responden sekolah (110;88\%) dan berpendidikan SD (75; 68,2\%). Sebagian besar responden bekerja sebagai nelayan yaitu 73 orang $(58,4 \%)$. Karakteristik responden meliputi umur, pendidikan dan pekerjaan disajikan pada Tabel 1.

Tabel 2 menggambarkan bahwa sebagian besar lansia berada pada kategori fungsi keluarga kurang, dukungan sosial keluarga dan masyarakat rendah serta kualitas hidup kurang yaitu masing-masing $72,0 \%, 54,4 \%, 67,2 \%$ dan $62,4 \%$. Variabel dukungan sosial pasangan sebagian besar dalam kategori tinggi yaitu sebesar $54,4 \%$. Hasil analisis bivariat dengan uji chi square didapatkan bahwa seluruh variabel berhubungan secara bermakna dengan nilai $\mathrm{p}<0,05$, seperti terlihat pada Tabel 3 .

Hasil analisis multivariat menunjukan bahwa hanya variabel fungsi keluarga yang memiliki hubungan bermakna dengan kualitas hidup lansia $(\mathrm{p}<0,05)$, dengan peran sebesar 2,3 kali $(95 \% \mathrm{CI}$ : $1,02-5,45)$ terhadap peningkatan kualitas hidup lansia seperti terlihat pada Tabel 4 .

\section{DISKUSI}

Penelitian ini menunjukkan bahwa kualitas hidup lansia di wilayah kerja Puskesmas III Denpasar Selatan sebagian besar masih kurang. Hal ini dapat disebabkan oleh kurangnya fungsi keluarga. Dukungan sosial pasangan, keluarga dan masyarakat tidak terbukti berhubungan dengan 
Tabel 1 Karakteristik lansia di wilayah kerja Puskesmas III Denpasar Selatan tahun 2013

\begin{tabular}{lcc}
\hline Variabel & f & Persentase \\
\hline Umur & 65 & \\
60-74 tahun & 60 & 52,0 \\
75-84 tahun & & 48,0 \\
Pendidikan & 15 & \\
Tidak sekolah & 110 & 12,0 \\
Sekolah & 75 & 88,0 \\
SD & 25 & 68,2 \\
SMP & 10 & 22,7 \\
SMA & & 0,1 \\
Pekerjaan & 52 & \\
Tidak bekerja & 73 & 41,6 \\
Bekerja & 30 & 58,4 \\
Nelayan & 22 & 41,1 \\
Petani & 10 & 30,1 \\
Pedagang & 6 & 13,7 \\
Buruh & 4 & 8,2 \\
Sopir & 1 & 5,5 \\
Pelukis & 125 & 1,4 \\
Jumlah & & 100,0 \\
\hline
\end{tabular}

Tabel 2 Analisia univariat fungsi keluarga, dukungan sosial dan kualitas hidup di wilayah kerja Puskesmas III Denpasar Selatan tahun 2013

\begin{tabular}{lcc}
\hline Variabel & f & Persentase \\
\hline Fungsi keluarga & & \\
$\quad$ Kurang & 90 & 72,0 \\
$\quad$ Baik & 35 & 28,0 \\
$\begin{array}{l}\text { Dukungan sosial } \\
\text { pasangan }\end{array}$ & \\
$\quad$ Rendah & & \\
$\quad$ Tinggi & 57 & 45,6 \\
Dukungan sosial keluarga & 68 & 54,4 \\
$\quad$ Rendah & & \\
$\quad$ Tinggi & 68 & 54,4 \\
Dukungan sosial & 57 & 45,6 \\
masyarakat & & \\
$\quad$ Rendah & & \\
$\quad$ Tinggi & 84 & 67,2 \\
Kualitas hidup & 41 & 32,8 \\
$\quad$ Kurang & & \\
$\quad$ Baik & 78 & 62,4 \\
Jumlah & 47 & 37,6 \\
\hline
\end{tabular}

kualitas hidup lansia di wilayah penelitian. Hasil ini sejalan penelitian lain yang menunjukkan bahwa sebanyak $70 \%$ lansia dengan kualitas hidup kurang dan 30\% lansia dengan kualitas hidup baik. ${ }^{5}$ Penelitian tentang komponen kualitas hidup lansia di Cina menemukan bahwa interaksi lansia dengan lingkungan sekitar dan ikatan dalam keluarga sangat mempengaruhi kualitas hidup. ${ }^{6}$ Kualitas hidup merupakan persepsi individu terhadap posisi mereka dalam hidup ditinjau dari konteks budaya dan sistem nilai serta berhubungan dengan standar hidup, harapan, kesenangan dan perhatian. ${ }^{7}$ Kualitas hidup adalah indikator penting untuk menilai keberhasilan intervensi pelayanan kesehatan, baik dari segi pencegahan maupun pengobatan. Kualitas hidup tidak hanya mencakup domain fisik, tetapi juga kinerja dalam memainkan peran sosial, keadaan emosional, fungsi intelektual dan kognitif serta perasaan sehat dan kepuasan hidup. ${ }^{8}$

Hasil penelitian ini menunjukkan lansia dengan fungsi keluarga kurang memiliki kualitas hidup yang kurang yaitu 62 orang (68,9\%). Pada analisis bivariat terlihat ada hubungan yang signifikan antara fungsi keluarga dengan kualitas hidup lansia ( $\mathrm{PR}=2,63$; 95\%CI: 1,18-5,86; $\mathrm{p}=0,016$ ). Berdasarkan uji regresi logistik, tampak bahwa fungsi keluarga memiliki hubungan yang bermakna serta memiliki kontribusi tertinggi terhadap kualitas hidup lansia di wilayah kerja Puskesmas III Denpasar Selatan tahun 2013 ( $\mathrm{PR}=2,36$; 95\%CI: 1,02-5,45; $\mathrm{p}=0,046$ ). Hasil penelitian ini menunjukkan lansia dengan fungsi keluarga baik memiliki kualitas hidup yang baik. Hasil penelitian ini dapat dipengaruhi oleh lokasi penelitian yang dilaksanakan di kota yang memungkinkan adanya interaksi antar anggota keluarga yang mempengaruhi kualitas hidup lansia.

Keluarga mempunyai peranan yang besar dalam menentukan kesehatan seseorang yang nantinya akan berhubungan dengan kualitas hidup seseorang. Apabila keluarga bahagia akan berpengaruh pada perkembangan emosi para anggotanya. Kondisi emosi lansia pada umumnya sangat labil, terutama jika terjadi perubahan pola kehidupan. Kebahagiaan diperoleh apabila keluarga dapat memerankan fungsinya secara baik. Hasil penelitian ini sejalan dengan penelitian lain yang menunjukkan bahwa ada hubungan antara fungsi keluarga dengan kualitas hidup lansia. ${ }^{4}$ Penelitian lain juga menunjukkan bahwa ada hubungan yang signifikan antara fungsi keluarga dengan kualitas hidup lansia. ${ }^{9,10}$

Secara sosiologis keluarga dituntut berperan dan berfungsi dengan baik untuk mencapai masyarakat sejahtera yang dihuni oleh individu 
Tabel 3 Crude PR hubungan fungsi keluarga, dukungan sosial pasangan, keluarga dan masyarakat dengan kualitas hidup lansia

\begin{tabular}{|c|c|c|c|c|c|}
\hline \multirow[b]{2}{*}{ Variabel } & \multicolumn{2}{|c|}{ Kualitas hidup } & \multirow[b]{2}{*}{ PR } & \multirow[b]{2}{*}{$95 \% \mathrm{Cl}$} & \multirow[b]{2}{*}{ Nilai $p$} \\
\hline & Kurang & Baik & & & \\
\hline \multicolumn{6}{|c|}{ Fungsi keluarga } \\
\hline Kurang & $62(68,9 \%)$ & $62(68,9 \%)$ & 2,63 & $1,18-5,86$ & 0,016 \\
\hline Baik & $16((45,7 \%$ & $16((45,7 \%$ & & & \\
\hline \multicolumn{6}{|c|}{ Dukungan sosial pasangan } \\
\hline Rendah & $30(52,6 \%)$ & $30(52,6 \%)$ & 0,46 & $0,22-0,97$ & 0,039 \\
\hline Tinggi & $48(70,6 \%)$ & $48(70,6 \%)$ & & & \\
\hline \multicolumn{6}{|c|}{ Dukungan sosial keluarga } \\
\hline Rendah & $48(64 \%)$ & $48(64 \%)$ & 2,16 & $1,03-4,51$ & 0,039 \\
\hline Tinggi & $30(60 \%)$ & $30(60 \%)$ & & & \\
\hline \multicolumn{6}{|c|}{ Dukungan sosial masyarakat } \\
\hline Rendah & $58(69 \%)$ & $58(69 \%)$ & 2,34 & $1,09-5,05$ & 0,028 \\
\hline Tinggi & $20(49 \%)$ & $20(49 \%)$ & & & \\
\hline
\end{tabular}

Tabel 4 Adjusted PR hubungan fungsi keluarga, dukungan sosial pasangan, keluarga dan masyarakat dengan kualitas hidup lansia

\begin{tabular}{lcccc}
\hline & & \multicolumn{2}{c}{$\mathbf{9 5 \% C l}$} & Nilai p \\
\cline { 3 - 5 } Variabel & PR & Batas bawah & Batas atas & \\
\hline Fungsi keluarga & 2,36 & 1,02 & 5,45 & 0,046 \\
Dukungan sosial pasangan & 0,54 & 0,25 & 1,18 & 0,124 \\
Dukungan sosial keluarga & 1,88 & 0,86 & 4,11 & 0,113 \\
Dukungan sosial masyarakat & 1,89 & 0,83 & 4,29 & 0,126 \\
\hline
\end{tabular}

$\mathrm{R}^{2}=0,152$

(anggota keluarga) yang bahagia dan sejahtera. Fungsi keluarga perlu diamati sebagai tugas atau kewajiban yang harus diperankan oleh keluarga sebagai lembaga sosial terkecil di masyarakat. Hasil penelitian ini didukung oleh penelitian lain yang menunjukkan bahwa lansia yang tinggal bersama keluarga memiliki kualitas hidup yang lebih baik daripada lanjut usia yang tinggal di panti werdha. ${ }^{11}$ Hal ini dikarenakan lanjut usia yang tinggal bersama keluarga di rumah tidak hanya mendapatkan perawatan fisik, namun juga mendapatkan kasih sayang, kebersamaan, interaksi atau komunikasi yang baik, serta menerima bantuan dari anggota keluarga yang merupakan fungsi dari keluarga. ${ }^{11}$ Umumnya lansia menghadapi kelemahan, keterbatasan dan ketidakmampuan sehingga kualitas hidup pada lansia menjadi menurun. Hal ini memerlukan fungsi keluarga yang baik untuk meningkatkan kualitas hidup lansia. ${ }^{7}$

Hasil analisis bivariat menunjukkan bahwa lansia dengan dukungan sosial dari pasangan yang rendah memiliki kualitas hidup kurang yaitu sebanyak 30 orang $(52,6 \%$; $P R=0,46$; $95 \% \mathrm{CI}$ :
$0,22-0,97 ; \mathrm{p}=0,039)$. Lansia dengan dukungan sosial keluarga yang rendah ditemukan memiliki kualitas hidup kurang yaitu sebesar 48 orang (64\%; $\mathrm{PR}=2,16 ; \quad 95 \% \mathrm{CI}: \quad 1,03-4,51 ; \mathrm{p}=0,039)$. Lansia dengan dukungan sosial masyarakat rendah juga ditemukan memiliki kualitas hidup kurang yaitu sebanyak 58 orang $(69,0 \%$; PR $=2,34$; $95 \%$ CI: 1,09 5,05; $\mathrm{p}=0,028)$. Hasil uji multivariat menunjukkan variabel dukungan sosial yang terdiri dari dukungan sosial pasangan, dukungan sosial keluarga dan masyarakat tidak berhubungan dengan variabel kualitas hidup lansia.

Tidak adanya hubungan yang bermakna pada analisis multivariat disebabkan adanya pengaruh variabel lain yang lebih kuat, mengingat variabel yang berpengaruh dianalisis sekaligus sehingga kemungkinan dikontrol oleh variabel yang lebih besar pengaruhnya. Hasil ini sejalan dengan penelitian lain menunjukkan bahwa terdapat tidak ada hubungan yang bermakna antara dukungan sosial dengan kualitas hidup lansia. ${ }^{12}$

Dukungan sosial pasangan tidak berhubungan dengan kualitas hidup lansia. Hal ini kemungkinan 
dipengaruhi oleh pasangan dari lansia yang juga merupakan seorang lansia dan sudah terjadi penurunan fungsi fisik serta perubahan psikologis yang menyebabkan dukungan sosial dari pasangan yang diberikan kepada lansia tidak mempengaruhi kualitas hidup lansia. Dukungan sosial keluarga juga tidak berhubungan dengan kualitas hidup lansia. Hal ini mungkin dipengaruhi oleh anggota keluarga dari lansia masih banyak yang bekerja di luar rumah sehingga waktu untuk bertemu dengan lansia masih kurang sehingga dukungan sosial keluarga tidak berhubungan dengan kualitas hidup lansia. Dukungan sosial masyarakat juga tidak berhubungan dengan kualitas hidup lansia. Hal ini barangkali karena penelitian ini berlokasi di kota sehingga dukungan sosial masyarakat kurang karena penduduk yang tinggal di kota lebih bersifat individual sehingga sosialisasi antar masyarakat tidak dilakukan dengan baik. Lansia yang tinggal di kota tidak merasakan bahwa dukungan dari masyarakat dapat meningkatkan kualitas hidup lansia.

\section{SIMPULAN}

Variabel fungsi keluarga berhubungan dengan kualitas hidup lansia di Wilayah Kerja Puskesmas III Denpasar Selatan. Variabel ini berkontribusi 2,3 kali untuk meningkatkan kualitas hidup lansia. Variabel lain seperti dukungan sosial pasangan, keluarga dan masyarakat didapatkan tidak berkontribusi terhadap kualitas hidup lansia, sehingga disarankan untuk meningkatkan fungsi keluarga dalam menjaga kesehatan lansia termasuk dalam hal kualitas hidup lansia di Wilayah Kerja Puskesmas III Denpasar Selatan.

\section{UCAPAN TERIMA KASIH}

Ucapan terima kasih disampaikan kepada lansia yang telah berpartisipasi dengan baik dalam penelitian ini.

\section{DAFTAR PUSTAKA}

1. Menkokesra. Paparan Menko Kesra pada Musrenbangnas 2012 Percepatan dan Perluasan Pembangunan Kesejateraan Rakyat Tahun 2013. Jakarta; 2013.

2. Dinkes Provinsi Bali. Profil Kesehatan Provinsi Bali. Denpasar; 2010.

3. Departemen Sosial RI. Lanjut Usia dalam Data dan Informasi. Jakarta: DBPSLU; 2002.

4. Ekawati. Hubungan Fungsi Keluarga dengan Kualitas Hidup Lansia; 2011.

5. Ismu Raudhah. Kualitas Hidup Lansia di Graha Residen Senior Karya Kasih Medan. Sumatera Utara; 2012.

6. Kelly Gillespie. Factor Determining Quality Of Life Perception Of The Elderly Residing In A Nursing Home And Assisted Living Facility. Medical Sciences, Gerontology and Geriatrics; 2011.

7. Sarafino EP. Health Psychology Biopsychosocial Interaction, $5^{\text {th }}$ edition. United States of America: John Wiley \& Sons; 2006.

8. WHO. Division of Mental Health and Prevention of Substance Abuse. 2004.

9. Wilanisa dan Iman. Hubungan Fungsi Keluarga dengan Kualitas Hidup Lansia di Kelurahan Wirobrajan Yogyakarta. 2012.

10. Septiani. Hubungan Dukungan Sosial dengan Kualitas Hidup Lansia di Rw 01 Kemiri Muka Depok. 2010.

11. Mahareza Y. Perbedaan Kualitas Hidup Lanjut Usia yang Tinggal di Panti Werdha dan yang Tinggal bersama Keluarga. Surabaya: Universitas Airlangga; 2008.

12. Meta Amelia Widya Saputri, Endang Sri Indrawati. Hubungan Antara Dukungan Sosial dengan Kualitas Hidup Lansia di Panti Wreda Wening Wardoyo Jawa Tengah. 2011.

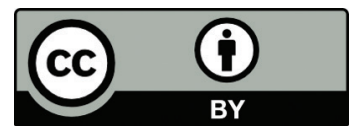

This work is licensed under a Creative Commons Attribution 